Nucl ear prot ei $n$ i mport, but not mRNA export, i s def ective i $n$ al I Saccharomyces cer evi si ae mit ant s that produce temper at ure- sensi t i ve for $n s$ of the Ran GTPase homol ogue Gsp1p

\begin{tabular}{|l|l|}
\hline 著者 & OK M NOGUCH E, HAYASH N, N SH MDTO T \\
\hline $\begin{array}{l}\text { j our nal or } \\
\text { publ i cat i on ti tl e }\end{array}$ & Nol ecul ar and Gener al Genet i cs \\
\hline vol une & 257 \\
\hline number & 6 \\
\hline page range & 624634 \\
\hline year & 1998 O4 \\
\hline URL & ht t p: //hdl . handl e. net /10098/1628 \\
\hline
\end{tabular}




\section{Nuclear protein import, but not mRNA export, is defective in all Saccharomnyces cerevisiae mutants that produce temperature-sensitive forms of the Ran GTPase homologue Gsp1p}

\begin{abstract}
A series of ts mutations in the GSPI gene of Saccharomyces cerevisiae was isolated by error-prone PCR. A total of 25 ts gspl strains was obtained. Each of these mutants showed between one and seven different amino acid alterations. In several of these ts gspl strains, the same amino acid residues in Gsplp were repeatedly mutated, indicating that our screen for ts gsp 1 mutations was saturating. All of the ts gspl strains isolated had a defect in nuclear protein import, but only 16 of the 25 ts gspl strains had a defect in mRNA export. Thus, Gsplp is suggested to be directly involved in nuclear protein import, but not in mRNA export. Following release from $\alpha$-factor arrest, 11 of the ts $g s p l$ mutants arrested in $\mathrm{Gl}$; the remainder did not show any specific cell-cycle arrest, at $37^{\circ} \mathrm{C}$, the nonpermissive temperature. While the mutants that are defective in both mRNA export and protein import have a tendency to arrest in $\mathrm{G1}$, there was no clear correlation between the cell cycle phenotype and the defects in mRNA export and nuclear protein import. Based on this, we assume that Ran/Gsplp GTPase regulates the cell cycle and the nucleus/cytosol exchange of macromolecules through interactions with effectors that were independent of each other, and are differentially affected by mutation.
\end{abstract}

Key words Ran - Gsp1 - Nuclear protein import . RNA export

Communicated by C. P. Hollenberg

M. Oki $\cdot$ E. Noguchi $\cdot$ N. Hayashi ${ }^{1} \cdot$ T. Nishimoto $(凹)$

Department of Molecular Biology,

Graduate School of Medical Science,

Kyushu University, Higashi-ku,

Fukuoka 812-8582, Japan

Fax: + 81-92-642-6183;

e-mail: nishi@molbiol.med.kyushu-u.ac.jp

Present address.

${ }^{1}$ Cancer Research Institute, Kanazawa University,

Kanazawa, Ishikawa 920, Japan

\section{Introduction}

The Ran GTPase gene was originally isolated as a member of the Ras superfamily, using a mixed-oligonucleotide probe based on a conserved Ras domain, from a cDNA library constructed with RNA from an undifferentiated human teratocarcinoma, and is designated as TC4 (Drivas et al. 1990). RCC1 was isolated as a human gene that complements a temperature-sensitive (ts) $\mathrm{rccl}^{-}$mutant, tsBN2, of the hamster BHK21 cell line (Kai et al. 1986; Ohtsubo et al. 1987). On the other hand, a protein of $24 \mathrm{kDa}$ that co-purifies with $\mathrm{RCC1}$ from HeLa cells was designated as Ran (Bischoff and Ponstingl 1991a). Subsequently, Bischoff and Ponstingl (1991b) found that Ran is identical to TC4 and that $\mathrm{RCCl}$ is a GDP/GTP exchange factor for the Ran/TC4 GTPase. They have also purified the Ran GTPase activating protein, designated as RanGAP1, which turned out to be a mammalian homologue of Saccharomyces cerevisiae Rnalp (Bischoff et al. 1995a, b). rnal-1, a ts mutant of the RNAI gene was isolated as a mutant that is defective in tRNA splicing (Hopper et al. 1987). Like RanGAP1, RCC1 is conserved in evolution. Temperature-sensitive mutants for $R C C 1$ homologues have been isolated in studies of diverse aspects of cell biology in yeast species - as mRNA splicing (prp20) (Aebi et al. 1990), signal transduction (sm 1-1) (Clark and Sprague 1989) and mRNA export (mtrl) (Kadowaki et al. 1993) in $S$. cerevisiae, and as mutants that are defective in cell cycle regulation (pim1-dl) in Schizosaccharomyces pombe (Matsumoto and Beach 1991; Sazer and Nurse 1994).

Independently, Ran GTPase has been found to be essential for nuclear localization signal (NLS)-dependent nuclear protein import (Moore and Blobel 1993; Melchior et al. 1993). In addition to nuclear protein import, the phenotype of $\mathrm{rcll}^{-}$mutants indicates that Ran GTPase is involved in mRNA export as well. Indeed, the GTP-bound form of Ran GTPase is required for mRNA export (Schlenstedt et al. 1995a; Richards et al. 1997). 
Taking all these results into account, it can be argued that the pleiotropic phenotype of $\mathrm{rccl}^{-}$is a consequence of defects in nuclear pore transport function. However, we have previously found that premature activation of $\mathrm{p} 34^{\mathrm{cdc} 2} /$ cyclin $\mathrm{B}$, which is induced by loss of RCC1 function in tsBN2 cells, can be prevented by nuclear injection of GTP-Ran (Ohba et al. 1996), indicating that some nucleoplasmic processing step is also dependent on GTP-Ran. Indeed, there is a nuclear Ran-binding protein, Yrb2p (Noguchi et al. 1997), in S. cerevisiae, which specifically binds to GTP-Ran. Disruption of the YRB2 gene does not cause any defect in mRNA export or NLS-dependent nuclear protein import (Noguchi et al. 1997). Therefore, Ran does not seem to be solely required for nucleus/cytosol exchange of macromolecules.

Thus far, several proteins have been found to possess a so-called Ran-binding domain (reviewed by Sazer 1996; Seki et al. 1996). Of these, Yrblp, disruption of which impairs nuclear import (Schlenstedt et al. 1995b), and RanBP2/NUP358, which is localized at the end of the cytoplasmic filament of nuclear pores (Yokoyama et al. 1995; Wu et al. 1995), are involved in nucleus/ cytosol exchange of macromolecules, whereas Yrb2p is not (Noguchi et al. 1997). In order to determine how Ran GTPase controls its downstream functions, we have isolated a series of temperature-sensitive mutants for the $S$. cerevisiae Ran homologue, Gsplp (Belhumeur et al. 1993).

\section{Materials and methods}

Strains and media

All the $S$. cerevisiae strains used in this study are described in Table 1. They were constructed by standard genetic manipulations (Kaiser et al. 1994). Transformation of S. cerevisiae was carried out by a modified LiCl method using DMSO (Hill et al. 1991). Selection against Ura $^{+-}$strains was carried out by culturing on solid synthetic media containing $1 \mathrm{mg} / \mathrm{ml} 5$-fluoroorotic acid (5-FOA) (Boeke et al. 1984). The media used for $S$. cerevisiae and bacteria have been described previously (Nishiwaki et al. 1987).

Construction of plasmids

The 1.9-kb HinclI-Sspl and the 3.3-kb Nsil-Xbal fragments of pBTCNRIHB4.1 (Kadowaki et al. 1993), both of which contain the open reading frame (ORF) of Gsplp, were isolated and, respectively, inserted into the Hincll site of pRS314, resulting in pF314GSP1, and the $N$ sil/Xbal site of pUC28, resulting in pUC28NXCNRI.

Disruption of the $G S P 1$ gene.

The $1.75-\mathrm{kb}$ HIS3 fragment of YIpI (Parent et al. 1985) was isolated and inserted into the BamHI site of pBluescriptIISK $(+)$, resulting in pSKHIS $3 \beta$; the $1.75-\mathrm{kb} S$ peI-Smal fragment containing the HIS 3 ORF was then recovered from pSKHIS $3 \beta$ and inserted into the SpeI/Ball site of pUC28NXCNR1, resulting in pUC28CNRHIS3. The Xbal-Sphl fragment of pUC28CNRHIS3 was used to disrupt the GSPI locus of the S. cerevisiae strain N43 by transformation. Disruption of the GSPI gene was confirmed by Southern analysis.

Table 1 Plasmids and yeast strains used in this study

\begin{tabular}{|c|c|c|c|}
\hline & Relevant markers & Comment/genotype & Source \\
\hline \multicolumn{4}{|l|}{ Plasmids } \\
\hline pBTCNRIHB4.1 & & pBluescriptIISK $(+)$ with $G S P I / C N R I$ fragment & $\begin{array}{l}\text { Kadowaki et al. } \\
\text { (1993) }\end{array}$ \\
\hline pF314GSPI & CEN TRPI GSPI & $\begin{array}{l}\text { pRS314 with } 1.9-\mathrm{kb} \text { GSPl fragment at HincII/ } \\
\text { SspI site }\end{array}$ & This study \\
\hline $\mathrm{pF} 314 \mathrm{gspl}{ }^{\mathrm{ts}}$ & CEN TRPI gspl ${ }^{i s}$ & $\begin{array}{l}\text { pRS314 with } 1.9 \text {-kb gsp } I^{t s} \text { fragment at Hincll/ } \\
\text { SspI site }\end{array}$ & This study \\
\hline pSKHIS $3 \beta$ & & pBluescriptIISK $(+)$ with 1.75 -kb HIS3 fragment & This study \\
\hline pUC28NXCNR1 & & $\begin{array}{l}\text { pUC28 with } 3.3-\mathrm{kb} G S P I / C N R I \text { fragment at } \\
N \text { SII/Xbal site }\end{array}$ & This study \\
\hline pUC28CNRHIS3 & & pUC28NXCNRI with $1.75-\mathrm{kb}$ HIS3 fragment & This study \\
\hline $\mathrm{pFB} 1-33 \mathrm{C}$ & $\begin{array}{l}2 \mu \mathrm{m} U R A 3 \\
G A L \quad 10-H 2 B:: l a c Z\end{array}$ & $H 2 B N L S$ fused in frame to $\beta$-galactosidase & $\begin{array}{l}\text { Moreland et al. } \\
\quad(1987)\end{array}$ \\
\hline pRSCNR1 & $\begin{array}{l}\text { CEN URA3 GSPII } \\
\quad \text { CNRI }\end{array}$ & pRS316 with GSPI/CNRI fragment & A. Tartakoff \\
\hline Ylp351GSP1 & $L E U 2 G S P 1$ & Ylp351 with $1.95-\mathrm{kb} G S P 1$ fragment ${ }^{\mathrm{a}}$ & This study \\
\hline Ylp35lgsp $1^{\text {ts }}$ & $L E U 2 \operatorname{gsp} 1^{t s}$ & Ylp351 with $1.95-\mathrm{kb} \mathrm{GSP}^{\text {ts }}$ fragment $^{\mathrm{a}}$ & This study \\
\hline \multicolumn{4}{|l|}{ Yeasts } \\
\hline S. cerevisiae $\mathrm{N} 43$ & & 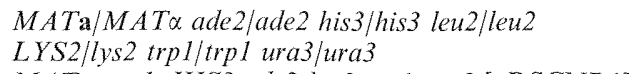 & $\begin{array}{l}\text { Noguchi et al. } \\
\text { (1997) }\end{array}$ \\
\hline S. cerevisiae $\mathrm{N} 43-6 \mathrm{C}$ & & MATa gspl::HIS3 ade2 leu2 trp1 ura3 [pRSCNR1] & This study \\
\hline $\begin{array}{l}\text { S. cerevisiae } \\
\text { N43-6C-GSP1 }\end{array}$ & & $\begin{array}{l}\text { MATa } \triangle \text { gspl }: \text { HIS } 3:: \text { GSP } 1:: L E U 2 \text { ade } 2 \text { leu } 2 \\
\quad \text { trp } 1 \text { ura3 }\end{array}$ & This stydy \\
\hline S. cerevisiae $\mathrm{N} 43-6 \mathrm{C}-\mathrm{gspl} \mathrm{l}^{\mathrm{ts}}$ & & $\begin{array}{l}\text { MATa } \triangle \text { gsp } 1:: \text { HIS } 3:: g s p I^{i s}:: L E U 2 \text { ade } 2 \text { leu } 2 \\
\quad \text { trpl ura3 }\end{array}$ & This study \\
\hline
\end{tabular}

\footnotetext{
a Ylp351 is described by Hill et al. (1986)
} 


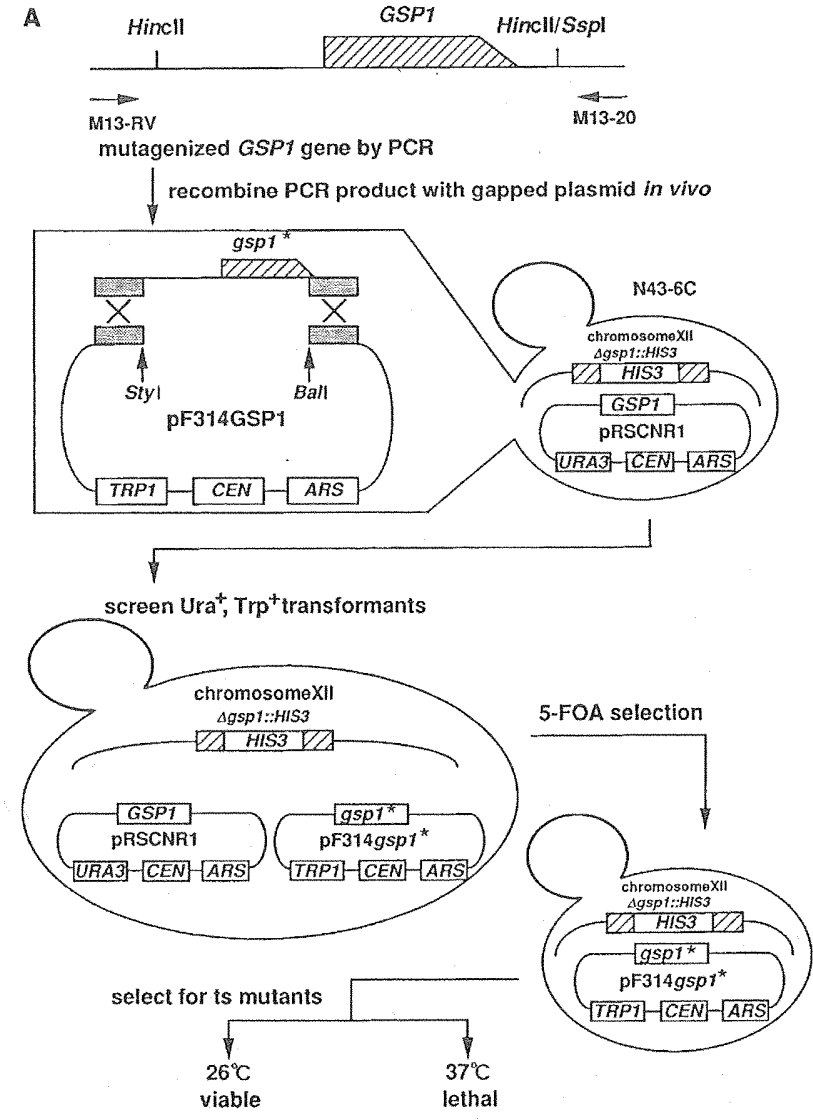

B Hindill partial digest

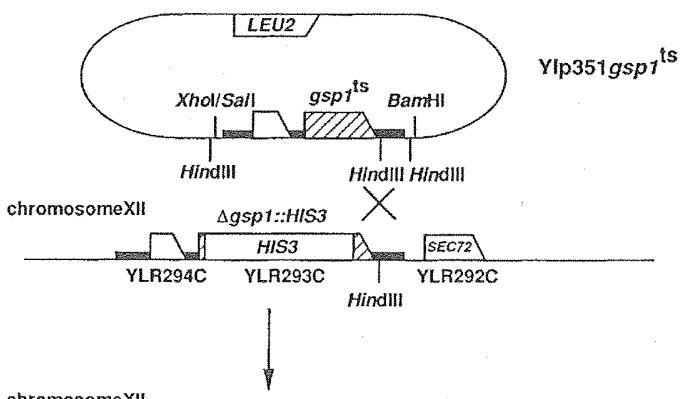

chromosomext

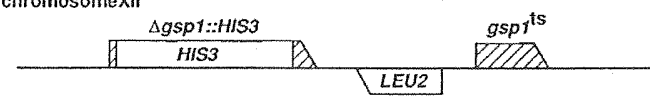

Fig. 1A, B Schematic preparation of ts gsp / strains. A Isolation of mutated ts $g s p 1$ genes. The GSPI gene was amplified under mutagenic PCR conditions as described in Materials and methods, using the indicated primers. The PCR product was then cotransformed into N43-6C together with a gapped plasmid (pF314GSP1) containing homology to both ends of the PCR product, based on the method previously described (Muhlrad et al. 1992). Transformants (Ura ${ }^{+}$ $\operatorname{Trp}^{+}$) were selected for ts mutants as described in Materials and methods. gsp $I^{*}$ indicates the mutagenized GSPI gene. B Integration of the ts $g s p l$ into the chromosomal GSPI site. YIp351gspl ${ }^{\text {ts }}$ plasmids were integrated into the HindIII site on chromosome XII of S. cerevisiae indicated by the X. YLR294C and YLR292C are open reading frames on $S$. cerevisiae chromosome XII

\section{Mutagenesis}

The GSPl gene was mutagenized by error-prone PCR (Beckman et al. 1985; Leung et al. 1989) as follows. Using as M13-20 and M13 reverse primers (TaKaRa), the GSP1 gene carried on pF314GSP1 was amplified with 5 units of Taq polymerase in PCR buffer $(7 \mathrm{mM}$ $\mathrm{MgCl}_{2}, 50 \mathrm{mM} \mathrm{KCl}, 10 \mathrm{mM}$ TRIS- $\mathrm{HCl} \mathrm{pH} 8.3,0.01 \%$ gelatin, $0.2 \mathrm{mM}$ dGTP, $0.2 \mathrm{mM}$ dATP, $1 \mathrm{mM}$ dCTP, $1 \mathrm{mM}$ dTTP, and $0.5 \mathrm{mM} \mathrm{MnCl}$ ) for 30 cycles $\left(94^{\circ} \mathrm{C}, 1 \mathrm{~min} ; 45^{\circ} \mathrm{C}, 1 \mathrm{~min} ; 72^{\circ} \mathrm{C}\right.$, $1 \mathrm{~min}$ ).

Site-directed mutagenesis was performed on pF314GSP1 using the site-directed mutagenesis system Mutan-K (TaKaRa).

Nuclear protein import assay

S. cerevisiae ts $g s p I$ strains carrying $\mathrm{pFB} 1-33 \mathrm{C}$ were cultured in synthetic medium containing raffinose, but lacking uracil, at $26^{\circ} \mathrm{C}$ until the early $\log$ phase, and then incubated at $37^{\circ} \mathrm{C}$ in synthetic medium containing galactose. When the growth rate began to fall significantly, cells were fixed and stained as described previously (Noguchi et al. 1997).

mRNA export assay

Cells were cultured at $26^{\circ} \mathrm{C}$ in YPD medium until early log phase, and then incubated at $37^{\circ} \mathrm{C}$. When the growth rate started to drop significantly, cells were fixed and in situ hybridization for mRNA was carried out using biotin-labeled oligo $(\mathrm{dT})_{50}$ as described previously (Noguchi et al. 1997).

\section{Results}

Isolation of ts mutations in $G S P I$

The GSP1 gene was amplified by error-prone PCR under the conditions described in Materials and methods. Amplified DNA fragments were introduced into the $S$. cerevisiae strain N43-6C ( $\Delta g s p 1::$ HIS3 [pRSCNR1]) (Table 1), together with the gapped pF314GSP1 plasmid (CEN, TRPI, GSPI) from which the GSPI ORF had been removed by digestion with the restriction enzymes StyI and BalI, as described in Fig. 1A. Transfected cells were plated on synthetic medium lacking tryptophan and uracil at $26^{\circ} \mathrm{C}$. About $4000 \mathrm{Trp}^{+} \mathrm{Ura}^{+}$ colonies, some of which now carry the mutated GSPl gene on gapped pF314GSP1, appeared and were replated onto synthetic medium plates containing $1 \mathrm{mg} / \mathrm{ml}$ of 5-FOA, which selects against the URA3 plasmid pRSCNR1. After incubation at $26^{\circ} \mathrm{C}$ for about 3 days, 2093 colonies were recovered. Thus, the survival rate following mutagenesis was $52 \%$. These colonies were replated onto YPD plates, which were subsequently incubated either at $26^{\circ} \mathrm{C}$, the permissive temperature, or at $37^{\circ} \mathrm{C}$, the nonpermissive temperature. A schematic representation of the mutant-isolation method is shown in Fig. 1A. Finally, $51 \mathrm{Trp}^{+}$colonies were found to be temperature-sensitive for cell proliferation at $37^{\circ} \mathrm{C}$. Representative results of temperature sensitivity tests are shown in Fig. 2.

In order to confirm the temperature sensitivity of the Gsplp encoded by the plasmids, the plasmids were iso- 
Fig. 2 Colony formation by ts gspl strains. The ts gspl strains were streaked onto two YPD plates as indicated. Plates were incubated either at $26^{\circ} \mathrm{C}$ (the permissive temperature), or at $37^{\circ} \mathrm{C}$ (the nonpermissive temperature) for 3 days
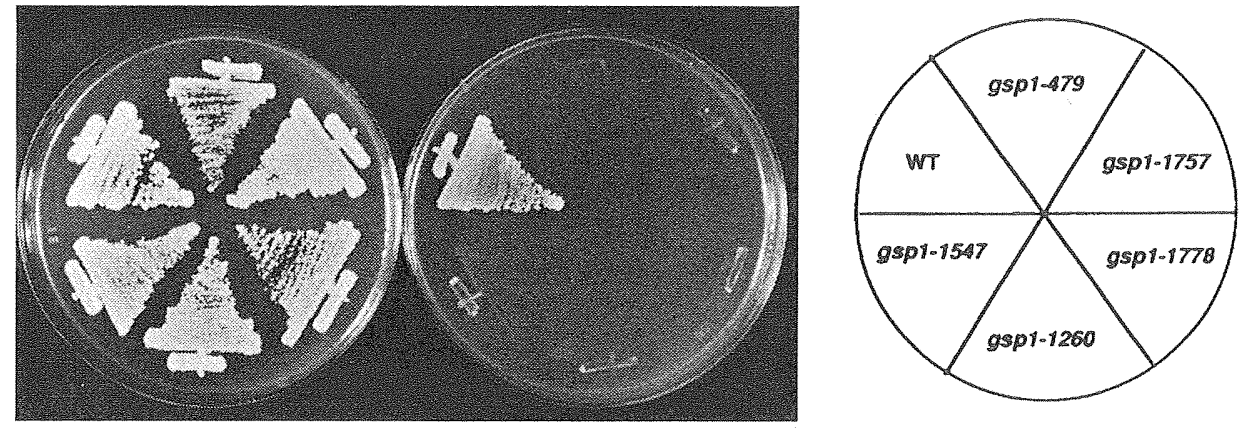

$26{ }^{\circ} \mathrm{C}$ $37^{\circ} \mathrm{C}$ lated from the ts $\operatorname{Trp}^{+}$clones and retransformed into the N43-6C strain ( $\Delta g s p 1:: H I S 3$ [pRSCNR1]). Transfected cells were plated on synthetic medium lacking tryptophan and uracil. After the wild-type plasmid pRSCNR1 had been eliminated by growth in 5-FOA, all of the $\operatorname{Trp}^{+}$colonies became temperature-sensitive for cell proliferation, indicating that the GSP1 gene carried by the $\mathrm{pF} 314$ plasmids derived from the original ts $\operatorname{Trp}^{+}$ clones indeed encoded a temperature-sensitive form of Gsplp.

Subsequently, we determined the nucleotide sequence of all 51 of the ts gspl genes and identified the mutation sites. The number of mutated amino acid residues in any given ts gspl gene ranged from 1 to 7 (Table 2). Several ts gspl genes that were found to contain the same set of amino acid alterations were discarded. Among the ts gspl clones, the same amino acid residues were repeatedly found to be mutated, as shown in Fig. 3. Interestingly, however, amino acid residues in the domains conserved in all small GTPases and essential for nucleotide binding (Boguski and McCormick 1993) were not mutated, with the exception of lysine in the third domain. Mutations in these domains are probably incompatible with survival. Indeed, the mutation of $\mathrm{K} 125 \mathrm{R}$ in the third domain alone is lethal (see Discussion).

Table 2 Phenotypes of ts $g s p /$ strains

\begin{tabular}{|c|c|c|c|c|}
\hline Mutation & Amino acid change & mRNA export ${ }^{a}$ & Protein import ${ }^{\mathrm{a}}$ & Arrest point \\
\hline $\operatorname{gspl}-1757$ & F28S & $-(\mathrm{C})$ & $-(\mathrm{D})$ & G1 \\
\hline gspl-1268 & $\mathrm{A} 85 \mathrm{D}$ & $-(\mathrm{C})$ & $-(\mathrm{D})$ & $\mathrm{G} 1$ \\
\hline$g s p 1-479$ & $\mathrm{I} 89 \mathrm{Y}$ & $-(\mathrm{C})$ & $-(\mathrm{D})$ & Gl \\
\hline$g s p l-16$ & D93E, W165R & $+(\mathrm{A})$ & $-(\mathrm{D})$ & Non-specific \\
\hline gspl -322 & $\mathrm{H} 50 \mathrm{Q}, \mathrm{Y} 149 \mathrm{H}$ & $-(\mathrm{D})$ & $-(\mathrm{B})$ & Gl \\
\hline gspl-882 & L52S, N156D & $-(\mathrm{C})$ & $-(\mathrm{D})$ & $\mathrm{G} 1$ \\
\hline $\operatorname{gspl} 1-1547$ & V103A, K125R & $-(\mathrm{C})$ & $-(\mathrm{D})$ & Non-specific \\
\hline gspl-1907 & M91V,I117A & $-(B)$ & $-(\mathrm{D})$ & G1 \\
\hline gspl-245 & K14N, K621, I89F & $-(\mathrm{B})$ & $-(\mathrm{D})$ & G1 \\
\hline $\operatorname{gspl} 1-1178$ & Y55H, Q86P, E160V & $-(\mathrm{B})$ & $-(C)$ & G1 \\
\hline gspl-1568 & H50L, Y $55 \mathrm{~N}, \mathrm{Y} 100 \mathrm{~F}$ & $-(\mathrm{B})$ & $-(\mathrm{D})$ & Non-specific \\
\hline gspl-1598 & R112S, I151F, F178L & $-(\mathrm{D})$ & $-(\mathrm{C})$ & G1 \\
\hline gspl-1651 & W66R, E160G, Q190P & $+(\mathrm{A})$ & $-(\mathrm{C})$ & Non-specific \\
\hline gspl-1819 & $\mathrm{K} 141, \mathrm{~K} 129 \mathrm{E}, \mathrm{D} 192 \mathrm{E}$ & $-(\mathrm{B})$ & $-(\mathrm{D})$ & Non-specific \\
\hline gspl-1894 & K14R, T34A, K62E & $+(\mathrm{A})$ & $-(\mathrm{D})$ & Non-specific \\
\hline$g s p 1-1060$ & V10D, E36G, E60V, N158D & $-(\mathrm{D})$ & $-(\mathrm{C})$ & G1 \\
\hline gspl-1486 & F58S, N84I, K144N, D150G & $+(A)$ & $-(\mathrm{D})$ & Non-specific \\
\hline gspl-640 & E9D, F63L, F92L, L121M, K129N & $+(A)$ & $-(\mathrm{C})$ & Non-specific \\
\hline gspl-1582 & K73N, I98V, K125R, K129I, L176I & $-(\mathrm{B})$ & $-(\mathrm{D})$ & G1 \\
\hline gspl-1778 & K 39M, F58L, N102I, R108K, E193D & $+(\mathrm{A})$ & $-(\mathrm{D})$ & Non-specific \\
\hline gspl-1968 & F37Y, H50R, T56S, Y82C, N102D & $+(\mathrm{A})$ & $-(\mathrm{D})$ & Non-specific \\
\hline$g s p l-1518$ & E36V, F92Y, N116S, Y199S, D213E, T207A & $-(\mathrm{B})$ & $-(\mathrm{D})$ & Non-specific \\
\hline$g s p l-1260$ & T56S, E60A, K125R, T137A, A183G, A208G & $+(\mathrm{A})$ & $-(\mathrm{D})$ & Non-specific \\
\hline gspl-1763 & L33S, V94A, N116T, T137A, K154M, N173D & $+(A)$ & $-(\mathrm{D})$ & Non-specific \\
\hline gspl-1817 & F28Y, T34A, I119T, K143R, Q147R, L195S, Q200H & $-(\mathrm{B})$ & $-(\mathrm{D})$ & Non-specific \\
\hline
\end{tabular}

a $(A),(B),(C)$ and (D) indicate the degree of residual activity (as a percentage of the wild-type activity) of ts mutants for mRNA export or nuclear protein import, as follows. (A), 80-100\% activity (more than $80 \%$ of cells showed normal activity); (B), $50-80 \%$; (C),
$20-50 \%$; (D), 0-20\%. More than 100 cells in the same field were examined. Class A phenotypes are regarded as wild type $(+)$; all others are adjudged to be abnormal $(-)$ 

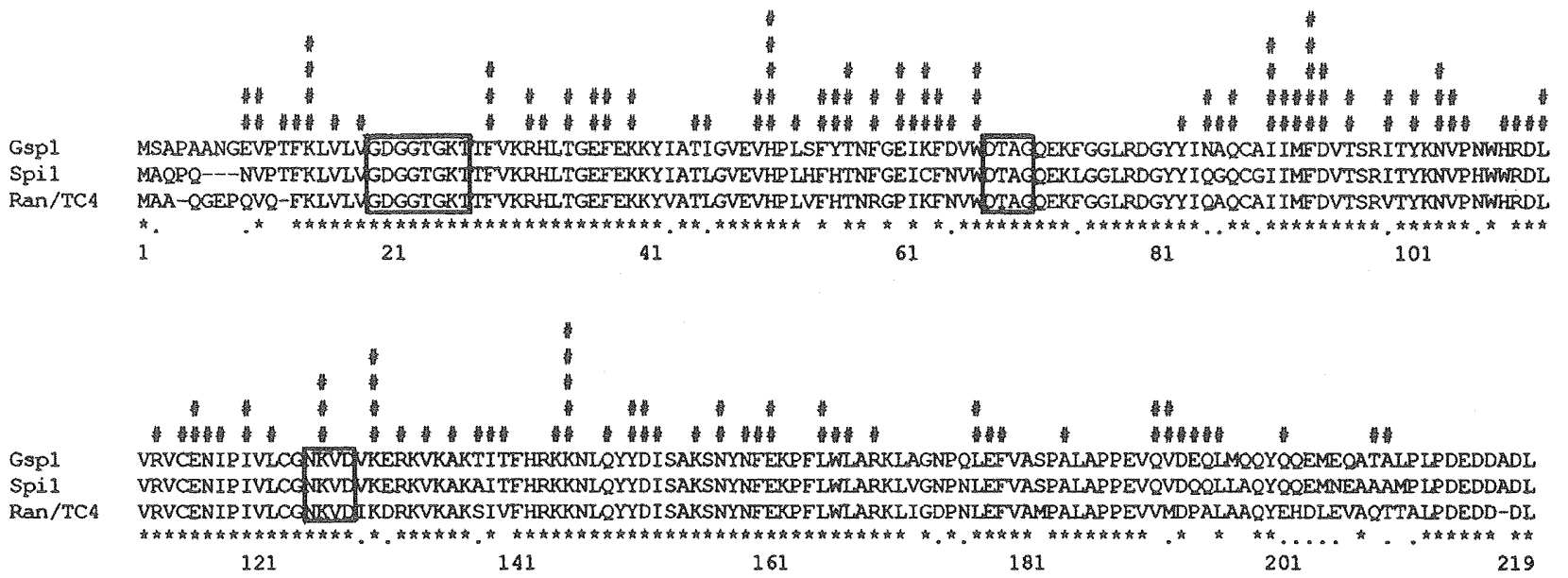

Fig. 3 Mutation sites found in ts gspl genes. The amino acid residues found to be changed in the 51 ts $g_{s p} 1$ genes examined are shown by the symbol \#. For comparison, the amino acid sequences of Spilp and Ran/TC4 GTPase are aligned. The numbers indicates the amino acid positions in Gsplp. The boxed regions are conserved among all small GTPases.The stars and dots indicate identical and chemically conserved amino acid residues, respectively

\section{Construction of ts gspl strains}

In order to characterize further the effect of ts $g s p l$ mutations on cell proliferation, the $1.95 \mathrm{mb}$ BamHI-Xhol fragment of the ts $g s p 1$ genes carried by $\mathrm{pF} 314 \mathrm{gsp} 1^{\text {ts }}$ plasmids was removed, and then inserted into the BamHI and Sall sites of the plasmid YIp351 (LEU2), resulting in YIp351gsp $1^{\text {ts }}\left(g s p 1^{t s}, L E U 2\right)$ (Fig. 1B). As a control, the wild-type GSPI gene was similarly introduced into the YIp351 plasmid (LEU2), resulting in YIp351GSP1 (GSP1, LEU2). YIp351 plasmids containing either wild-type GSPl or a ts gspl gene were partially digested with HindIII and then introduced into the strain N43-6C ( $\triangle g s p 1:: H I S 3$ [pRSCNR1]), in order to integrate ts gspl genes into the HindIII site localized 19 bp downstream of the 3' end of GSPI ORF (Fig. 1B). $\mathrm{Leu}^{+} \mathrm{Ura}^{+}$transformants were selected on synthetic medium plates lacking leucine and uracil, and then replated on synthetic medium containing 5-FOA to eliminate the wild-type plasmid pRSCNR1. Leu ${ }^{+}$colonies were replated onto YPD plates at $26^{\circ} \mathrm{C}$ or $37^{\circ} \mathrm{C}$ to determine their temperature sensitivities. The entire procedure is shown schematically in Fig. 1B.

Some of the ts gsp 1 genes derived from the original ts $\operatorname{Trp}^{+}$colonies were not ts for cell proliferation following the integration of mutated genes into the GSPI locus of the $S$. cerevisiae strain N43-6C. A total of $25 \mathrm{~S}$. cerevisiae $\mathrm{N} 43-6 \mathrm{C}-\mathrm{gsp} 1^{\text {ts }}$ strains possessing a ts mutation in the GSPI gene were obtained (Table 2).

Three of the 25 ts gsp 1 strains had a single amino acid alteration. The rest all contained several amino acid changes in the GSPI gene. In order to confirm the correlation between the amino acid change in Gsplp and the ts character, we introduced the amino acid changes found in ts gspl strains that contained either single or double mutations into the wild-type GSPI ORF of plasmid pF314GSP1, by using site-directed mutagenesis. Upon introduction of the resulting mutated pF314GSP1 into the strain N43-6C, it was found that all of the amino acid changes found in those ts gspl genes that had a single mutation caused yeast to become temperaturesensitive for cell proliferation. On the other hand, neither of the two amino acid changes found in the ts gspl genes possessing double mutations conferred the ts character on yeast. Both of the amino acid changes, therefore, were necessary to cause yeast to become temperature-sensitive in cases where ts gsp 1 strains possessed double mutations.

\section{Characterization of ts gspl strains}

In order to characterize the ts gspl mutations in liquid cultures, the growth curve of each ts gspl strains was determined. Representative results are shown in Fig. 4. Most ts mutants showed a clear growth defect even in liquid cultures. But some mutants, for example gspl1518 , showed considerable growth at $37^{\circ} \mathrm{C}$, the nonpermissive temperature, although they eventally arrested (data not shown). At the times indicated by the arrows in Fig. 4 when the growth rate of ts gspl strains started to drop significantly, the mutants' capacities for mRNA export were determined. Similarly, the ability to import proteins into the nucleus was determined in synthetic medium.

\section{Nuclear protein import}

Hydrolysis of GTP-Ran is essential for nuclear protein import (Moore and Blobel 1993; Melchior et al. 1993). We therefore investigated the abilities of ts $g s p l$ strains to import proteins bearing a nuclear localization signal into the nucleus. To this end, the plasmid pFB1-33C $(U R A 3)$, which encodes $\beta$-galactosidase fused in frame with the NLS from histone $\mathrm{H} 2 \mathrm{~B}$ at a site downstream of 

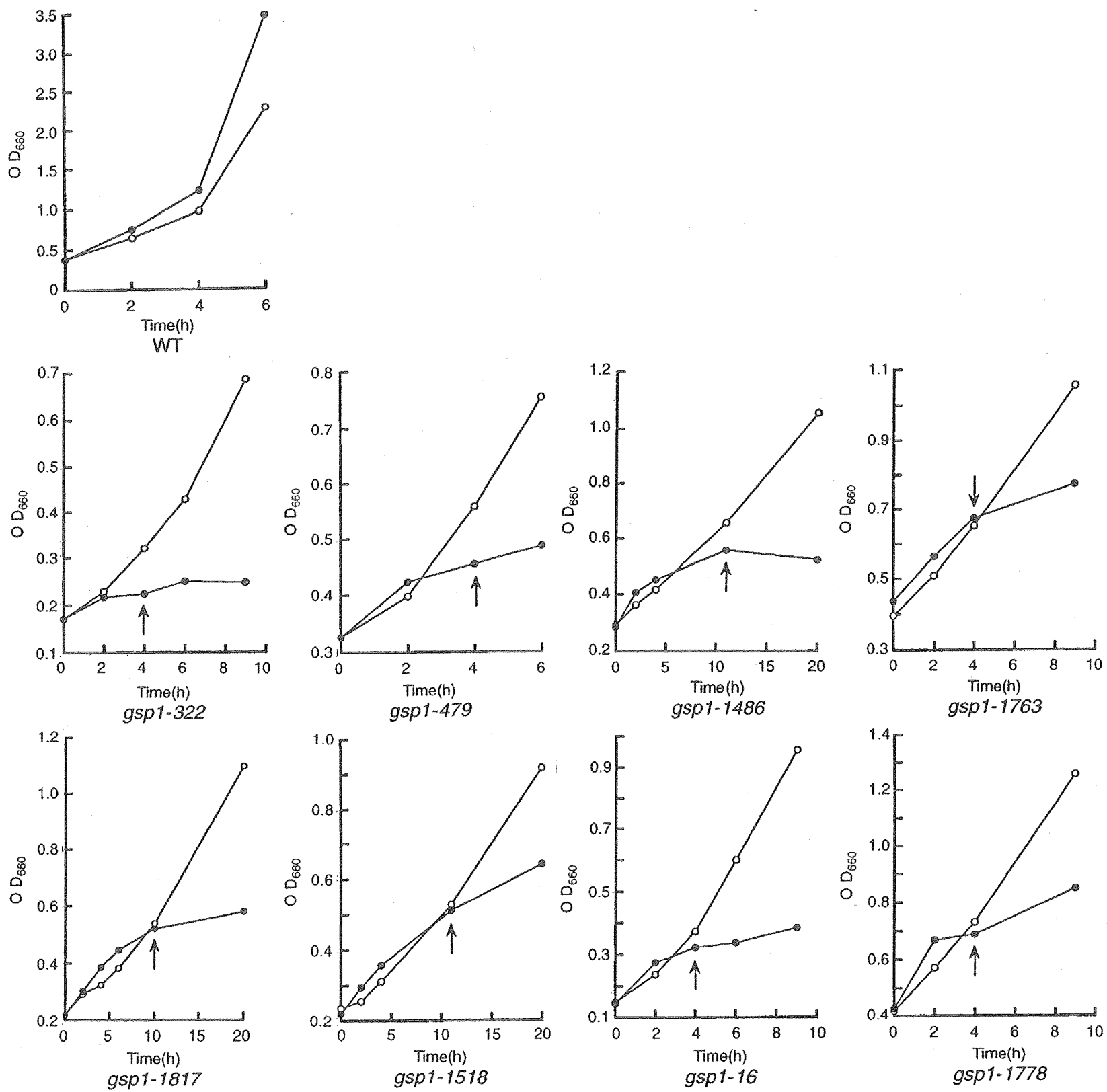

Fig. 4 Growth curves for ts $g S p I$ strains. Overnight cultures of GSPI and $g s p I^{\text {ts }}$ strains were diluted into YPD medium and grown for $4 \mathrm{~h}$ at $26^{\circ} \mathrm{C}$. Half of each culture was then shifted to $37^{\circ} \mathrm{C}$ (filled circles) and the other half was incubated further at $26^{\circ} \mathrm{C}$ (open circles). At the indicated times, $\mathrm{OD}_{660 \mathrm{~nm}}$ values were measured. At the times indicated by the arrows ( $4 \mathrm{~h}$ for ts gsp 1-16, ts gspl-322, ts gsp I-479, ts $g s p 1-1763$ and ts $g s p 1-1778 ; 10 \mathrm{~h}$ for ts $g s p 1-1817$; and $11 \mathrm{~h}$ for ts gsp 1-1486 and ts gsp 1-1518), cells were sampled to determine the localization of mRNA

the GAL10 promoter (Moreland et al. 1987), was introduced into the ts gspl strains. Transfected cells were plated on synthetic medium lacking uracil. Ura ${ }^{+}$ transformants were cultured to early log phase at $26^{\circ} \mathrm{C}$ in synthetic medium containing raffinose, but lacking

uracil, and then incubated at $37^{\circ} \mathrm{C}$, the nonpermissive temperature, in synthetic medium containing galactose. When the growth rate of ts gspl strains (Ura ${ }^{+}$) began to fall significantly, as shown in Fig. 4, cells were stained with anti- $\beta$-galactosidase antibodies. Representative results are shown in Fig. 5. In our wild-type $S$. cerevisiae strain N43-6C, nuclear protein import was sometimes slow at $26^{\circ} \mathrm{C}$, probably due to the lower temperature and the genetic background of our strain. Therefore, the capacity of the ts $g s p 1$ strains for nuclear protein import was determined at $37^{\circ} \mathrm{C}$ and compared with that of wild-type strains at the same temperature.

In most of the ts gsp 1 strains, NLS-dependent nuclear protein import was profoundly retarded. In Table 2 , we 
$\beta$-gal
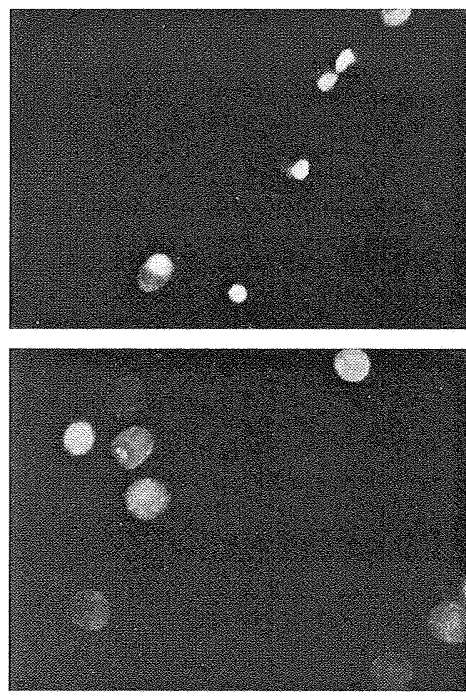

Hoechst
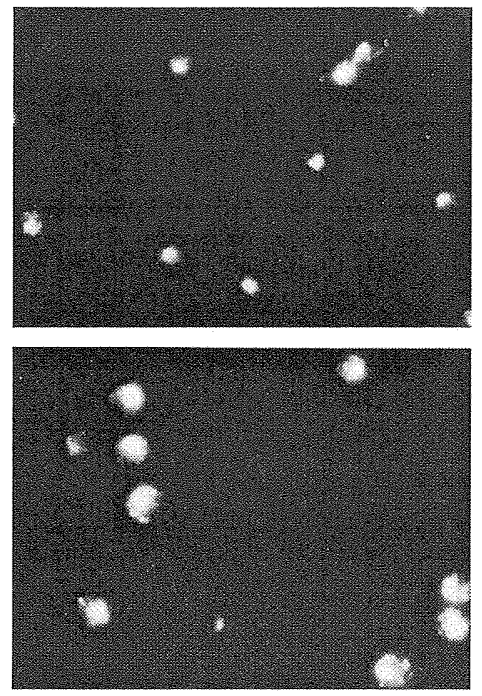

Phase
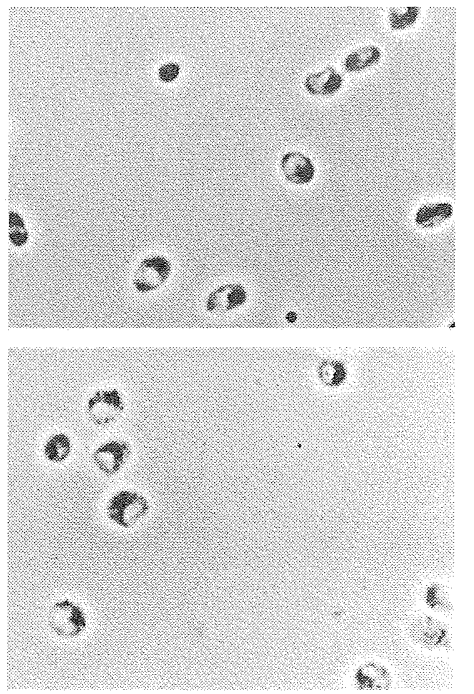

Tig. 5 Nuclear protein import in ts gspl strains. Wild-type and ts

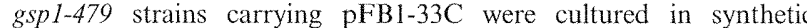
medium containing $2 \%$ raffinose, but lacking uracil, at $26^{\circ} \mathrm{C}$ until early $\log$ phase, and then incubated at $37^{\circ} \mathrm{C}$ in synthetic medium containing $2 \%$ galactose. When the growth rate began to fall significantly (see Fig. 4), cells were fixed and treated with an anti- $\beta$ galactosidase antibody raised in rabbit, followed by Texas redconjugated goat anti-rabbit antibody $(\beta$-gal). Cellular DNA was stained with Hoechst 33342 (Hoechst). Cells in the same field were observed by fluoresence and phase contrast (Phase) microscopy

list the ability of each ts mutant to import proteins into the nucleus relative to that of wild-type strain. There were no ts gspl strains which showed a normal nuclear protein import at $37^{\circ} \mathrm{C}$, the nonpermissive temperature (Table 2).

\section{mRNA export}

Defects in mRNA export are very common in $S$. cerevisiae prp $20^{-}$mutants and have also been reported in rna1-1 cells (reviewed by Sazer 1996; Seki et al. 1996). We therefore investigated the ability of ts gspl strains to export mRNA from the nucleus to the cytoplasm.

ts $g s p 1$ cells were cultured in liquid YPD medium at $26^{\circ} \mathrm{C}$ until early log phase, and then half of each culture was incubated further at $37^{\circ} \mathrm{C}$. At the times indicated by the arrows in Fig. 4, cells were fixed and processed for in situ hybridization with biotin-labeled oligo-dT. As controls, cells kept at $26^{\circ} \mathrm{C}$ were fixed and processed similarly. After hybridization, cells were stained with FITC-avidin and then the nucleus was counter-stained with Hoechst 33342 in PBS buffer. Representative results are shown in Fig. 6. As in the case of nuclear protein import, mRNA export was sometime retarded at $26^{\circ} \mathrm{C}$, even in the wild-type strain, as shown in Fig. $6 \mathrm{~A}$. At $37^{\circ} \mathrm{C}$, however, mRNA was efficiently exported in wild-type cells and in some ts gspl strains which showed no defect in mRNA export, while other ts mutants had no ability to export mRNA (Fig. 6B).

Nine out of the 25 ts gspl strains had no defect in mRNA export (Table 2). In the remainder, the capacity for mRNA export varied. The ability of each ts mutant to export mRNA is listed in Table 2 in comparison with that of wild-type strain.

\section{Cell cycle analysis}

In order to investigate the relationship between the Ran/ Gsplp GTPase cycle and cell cycle regulation, cultures of ts gspl strains were treated with $\alpha$-factor at $26^{\circ} \mathrm{C}$. Following release from $\alpha$-factor arrest, half of each culture was incubated at $37^{\circ} \mathrm{C}$, the nonpermissive temperature, and the other half was cultured at $26^{\circ} \mathrm{C}$, the permissive temperature. The progression of the cell cycle was monitored by FACS analysis (Fig. 7).

Of the ts gsp 1 mutants, 11, all of which have a defect in mRNA export, did not initiate a new cell cycle following release from $\alpha$-factor arrest at $37^{\circ} \mathrm{C}$, while they did enter a new cell cycle at $26^{\circ} \mathrm{C}$, the permissive temperature. At the nonpermissive temperature, these mutants were arrested at G1. The remaining mutants accumulated as cells possessing either G1 or G2 DNA

Fig. 6A, B mRNA export in ts $g s p 1$ strains. The strains ts $g s p 1-16$ and ts gsp 1-322 and, as a control, the wild-type strain N43-6C-GSP1 were cultured in YPD medium at $26^{\circ} \mathrm{C}$ until the early log phase. Cultures were then divided in half and one half was further incubated at $26^{\circ} \mathrm{C}$ (A), while the other half was transferred to $37^{\circ} \mathrm{C}(\mathrm{B})$. At the times indicated in Fig. 4, when the growth rate started to drop, cells were fixed and hybridized with biotin-labeled oligo $(\mathrm{dT})_{50}$, followed by incubation with FITC-avidin. Cellular DNA was stained with Hoechst 33342 (Hoechst). FITC and Hoechst fluorescence of the same fields of cells are shown, together with the corresponding phasecontrast views 
A

WT

$g s p 1-16$
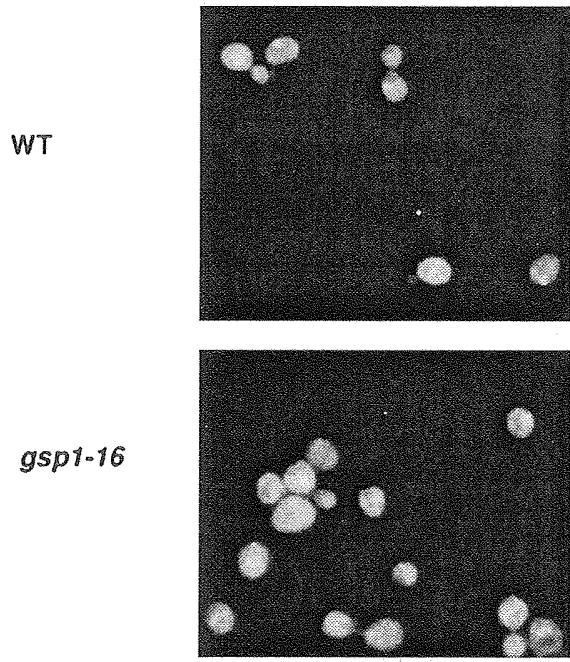

gspy-16

gsp:-322

FITC
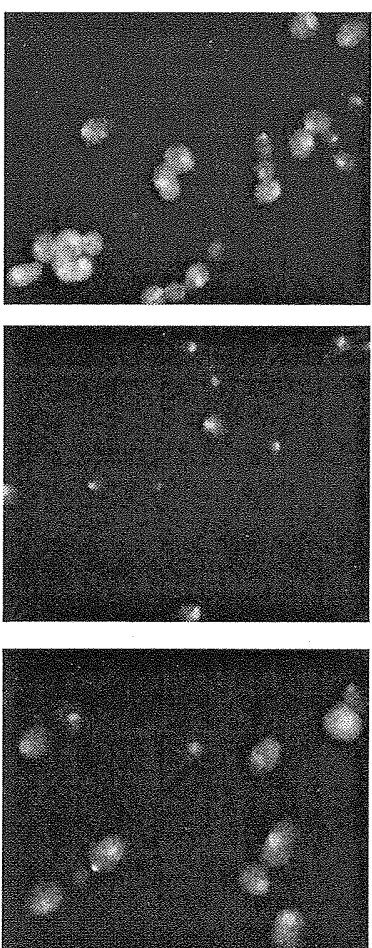

FITC
Hoechst
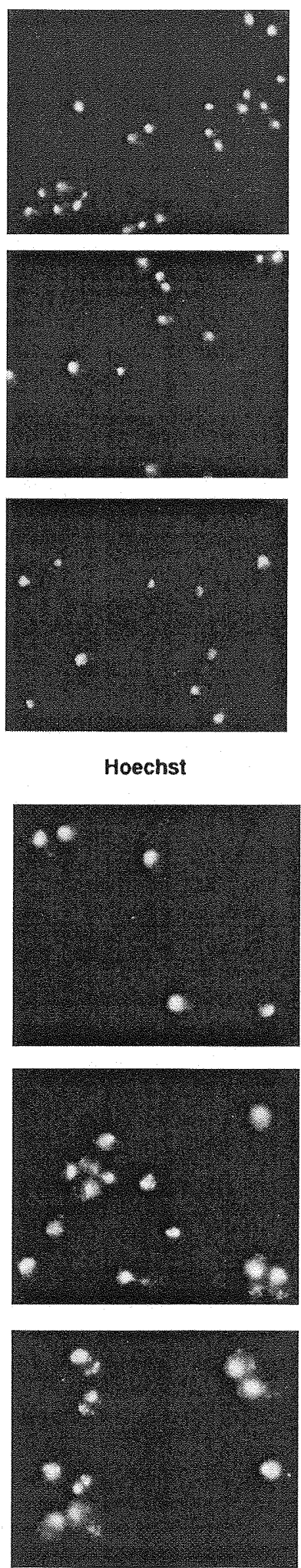

Phase
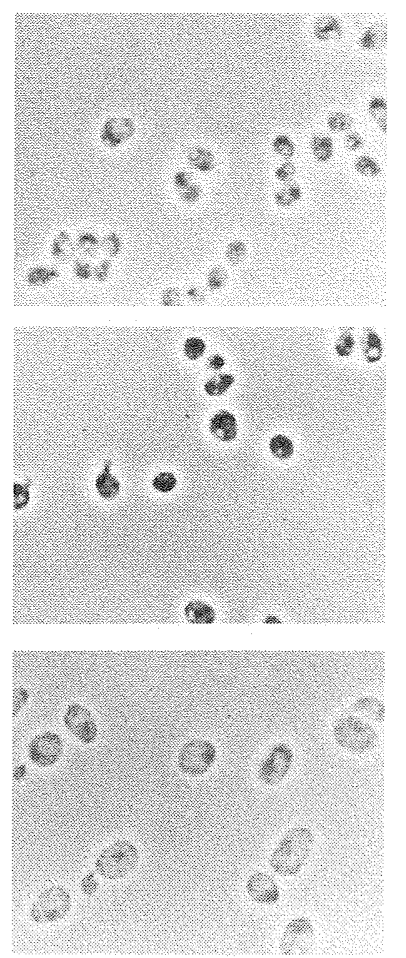

Phase
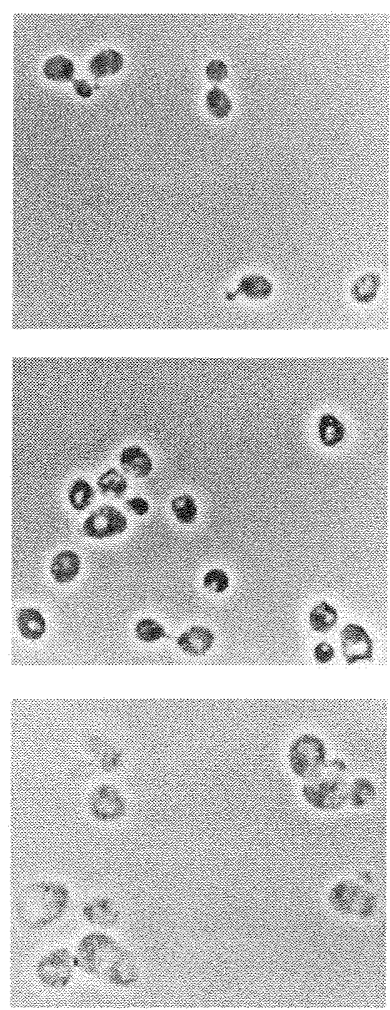
Fig. 7 Cell cycle analysis of ts gspl strains. ts gspl strains and wild-type strains were cultured in YPD medium at $26^{\circ} \mathrm{C}$ until an $\mathrm{OD}_{660 \mathrm{~nm}}$ of 0.1 and then incubated in the presence of $10 \mu \mathrm{g} / \mathrm{ml}$ of $\alpha$-factor for $2 \mathrm{~h}$ at $26^{\circ} \mathrm{C}$. Subsequently, fresh $\alpha$ factor $(20 \mathrm{\mu g} / \mathrm{ml}$ final concentration) was added and the cells were incubated at $26^{\circ} \mathrm{C}$ for another $2 \mathrm{~h}$. After the $\alpha$-factor had been washed out with distilled water, half of cells were incubated in YPD medium at $37^{\circ} \mathrm{C}$, and the other half at $26^{\circ} \mathrm{C}$. At the indicated times, cells were sampled and processed for FACS analysis. Top panel Wild-type cells. Middle panel ts gspl strains showing Gl arrest. Bottom panel ts gspl strains showing non-specific cell cycle arrest
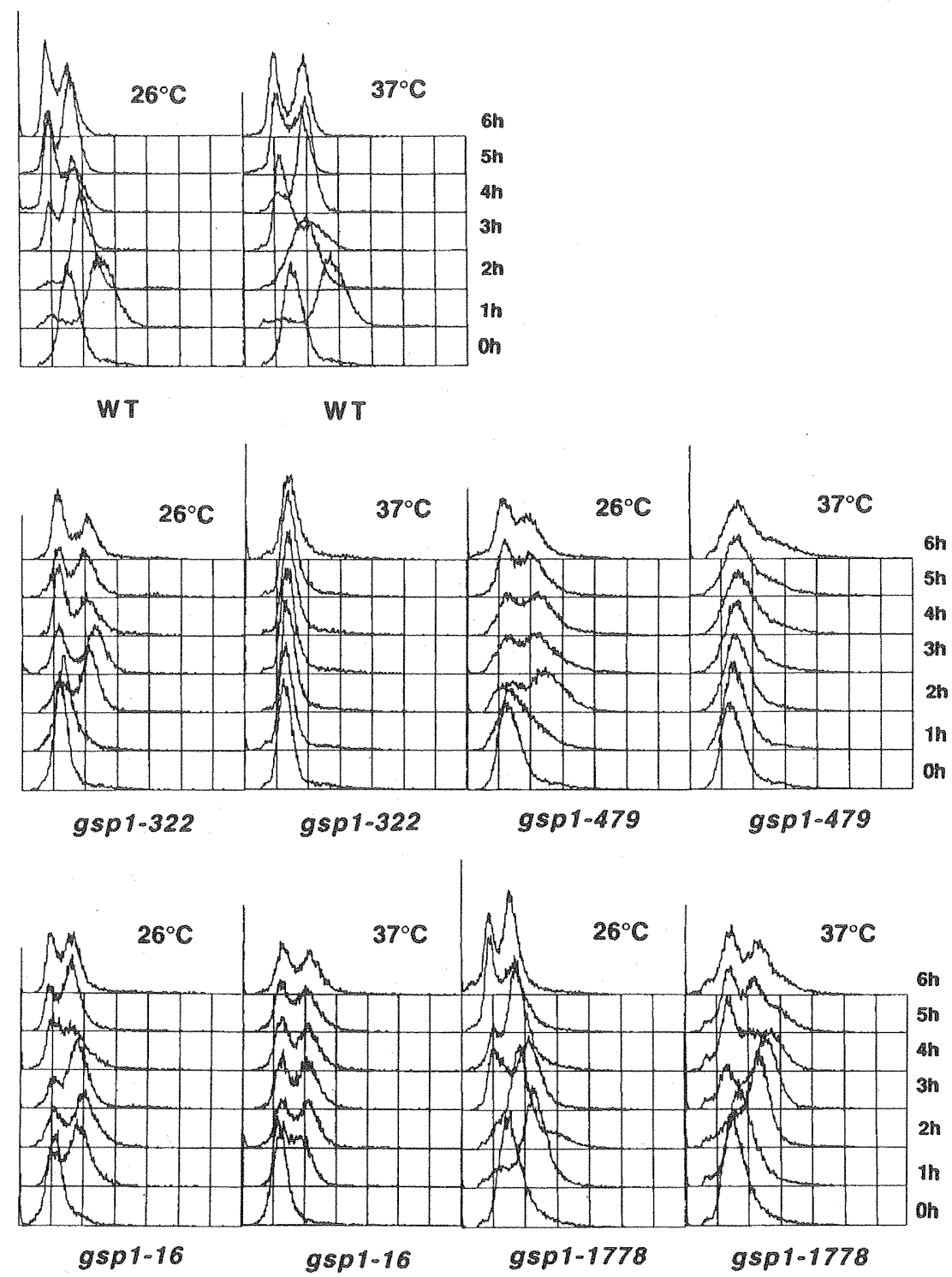

content at $37^{\circ} \mathrm{C}$, showing no clear cell cycle-specific arrest. Two representative examples of $\mathrm{G} 1$ and nonspecific cell cycle arrests are shown in Fig. 7.

Most of the ts gspl strains showed an aberrantly enlarged shape. Representative examples were shown in Fig. 8. The strains ts gspl-1757 and ts gspl-1778, respectively, arrest in G1 and in a non-specific manner (Table 2). Hence, the aberrant shape of ts $g s p l$ strains does not seem to be correlated with their cell cycle phenotype.

\section{Discussion}

In addition to ts gspl genes containing a single mutation, we isolated several other ts $g s p l$ genes in which the number of mutation sites ranges from 2 to 7 . Both of the amino acid changes found in double mutations are necessary to make yeast temperature sensitive. Thus, we can assume that all of the amino acid changes found in other ts gspl strains with multiple mutations are necessary for the temperature-sensitive growth phenotype. In this regard, it is noteworthy that the amino acid change of K125R in ts $g s p 1-1547$ is also present in two other mutants, ts gsp 1-1582 and ts gsp 1-1260, which, in addition to K125R, possess 5 and 6 amino acid changes, respectively. The concerted effects of these mutation sites may correspond to the effect of the amino acid change V103A in ts gsp1-1547. In the case of the $\mathrm{K} 125 \mathrm{R}$ mutation, an additional mutation is essential to make yeast temperature-sensitive for cell proliferation, since the GSPI plasmid containing the K125R mutation alone is lethal for $S$. cerevisiae (M. Oki, in preparation). 


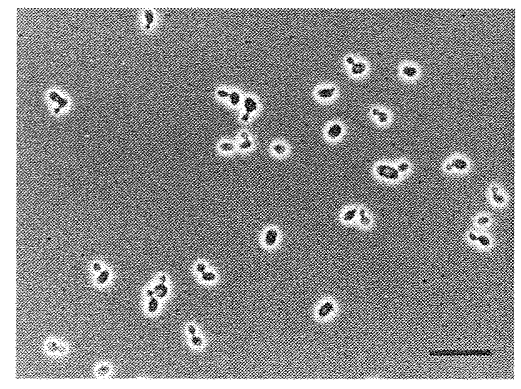

Wr

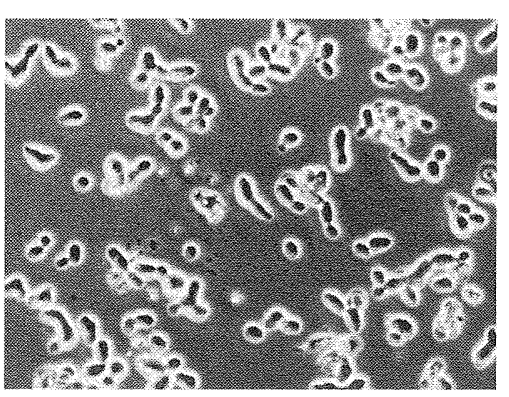

gspy-1757

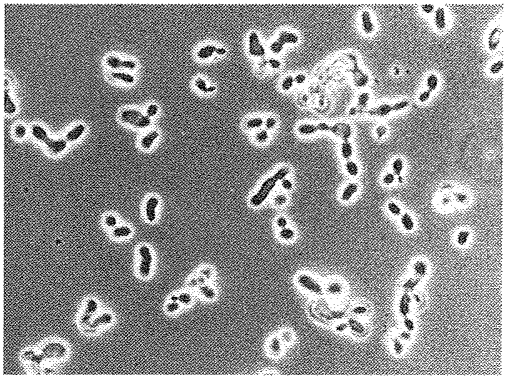

gsp1.1778

Fig. 8 Cellular morphology of ts gspl cells. ts gsp $1-1757$ and ts gspl-1778 and, as a control, wild-type strains were cultured at $26^{\circ} \mathrm{C}$ and photographed under phase-contrast optics. Bar $25 \mu \mathrm{m}$

Among the ts gspl genes obtained, some amino acids are repeatedly changed and several ts gspl genes were found to contain the same set of amino acid changes. Considering all these results together, we can surmise that our mutagenesis for ts gspl genes is almost saturating.

While nuclear protein import in our wild-type strain was sometimes retarded at $26^{\circ} \mathrm{C}$, it was normal at $37^{\circ} \mathrm{C}$. Thus, the abilities of ts gspl strains to import proteins into the nucleus were examined and compared with that of wild type strain at $37^{\circ} \mathrm{C}$. In this regard, it is not certain that the defect in nuclear protein import of ts gspl strains is directly related to the temperature-sensitive growth defect of these strains. Even so, the finding that all of the ts $g s p l$ strains isolated here have a defect in nuclear protein import is remarkable. It is consistent with the previous in vitro finding that the Ran GTPase is essential for nuclear protein import (Moore and Blobel 1993; Melchior et al. 1993). In contrast to nuclear protein import, defects in mRNA export are not universal among the ts gspl strains. This is surprising because accumulation of mRNA in the nucleus is frequently observed among $S$. cerevisiae prp $20^{-}$mutants and rnal-1 (Izaurralde and Mattaj 1995), although these mutants do not have a defect in Gsplp itself. The prp20- have a defect in the GDP/GTP exchange factor for Gsplp and the $r n a l-1$ has a defect in the GTPase-activating factor for Gsplp GTPase. Our present results indicate that the Gsplp is not directly involved in mRNA export, while it is directly required for NLS-dependent nuclear protein import.

By analogy with Ras GTPase, the events downstream of Gsplp action may depend on the function of effectors for the Gsplp GTPase. S. cerevisiae has been reported to contain a family of Ran/Gsplp GTPase-binding proteins (Dingwall et al. 1995), the number of which is still increasing (Sazer 1996). The ts mutations in the GSPI gene described here may affect these effectors differentially. While those ts gspl mutants that are defective in both nuclear protein import and mRNA export show G1 arrest, there are no ts gspl strains which arrest at G2 alone. This is curious, since ts srp 1, which is a ts mutant for importin $\alpha$ and is therefore defective in nuclear protein import, is arrested at $\mathrm{G} 2$ following release from $\alpha$-factor arrest (Loeb et al. 1995). The mutant Gsplp probably affects several downstream effectors, in addition to abrogating nuclear protein import. In this context, the finding that there are no ts gspl strains which arrest at $\mathrm{G} 2$ alone seems reasonable. The cell proliferation phenotype may be the concerted consequence of abnormal function of several Gsplp effectors which are affected by a given ts gsp 1 mutation. Obviously, many effectors for Gsplp GTPase remain to be uncovered. By isolating a suppressor for each ts gspl strain, we should be able to identify the effector(s) of Gsplp GTPase affected by any particular ts gsp 1 mutation.

During the preparation of this manuscript, Wong et al. (1997) reported the isolation of two ts gspl strains. Their sample of ts mutants is too small to allow a comprehensive genetic characterization of the function of Gsplp GTPase. However, these authors found that their ts mutants can be suppressed by overexpression of the $N T F 2$ gene. We are currently investigating the effect of overexpression of $N T F 2$ gene on our ts gspl strains.

Acknowledgements We thank Dr. S. Sakaguchi for the anti- $\beta$ galactosidase antibody, Dr. A. M. Tartakoff for the CNR1 plasmid, Drs. L. I. Davis and P. Silver for NLS-histone H2B, and Drs. H. Quadota and H. Seino for PCR mutagenesis. This work was supported by Grants-in-Aid for Specially Promoted Research and by the HFSP. The text was revised by Miss K. Miller (Royal English Language Centre, Fukuoka, Japan).

\section{References}

Aebi M, Clark MW, Vijayraghavan U, Abelson J (1990) A yeast mutant, PRP20, altered in mRNA metabolism and maintenance of the nuclear structure, is defective in a gene homologous to the human gene $R C C l$ which is involved in the control of chromosome condensation. Mol Gen Genet 224:72-80

Beckman RA, Mildvan AS, Loeb LA (1985) On the fidelity of DNA replication: manganese mutagenesis in vitro. Biochemistry 24:5810-5817

Belhumeur P, Lee A, Tam R, DiPaolo T, Fortin N, Clark MW (1993) GSP1 and GSP2, genetic suppressors of the prp20-1 mutant in Saccharomyces cerevisiae: GTP-binding proteins involved in the maintenance of nuclear organization. Mol Cell Biol 13:2152-2161 
Bischoff FR, Ponstingl $\mathrm{H}$ (1991a) Mitotic regulator protein $\mathrm{RCCl}$ is complexed with a nuclear ras-related polypeptide. Proc Nat Acad Sci USA 88:10830-10834

Bischoff FR, Ponstingl H (1991b) Catalysis of guanine nucleotide exchange on Ran by the mitotic regulator $\mathrm{RCCl}$. Nature 354:80-82

Bischoff FR, Krebber H, Smirnova E, Dong, W, Ponstingl H (1995a) Co-activation of RanGTPase and inhibition of GTP dissociation by Ran-GTP binding protein RanBP1. EMBO J $14: 705-715$

Bischoff FR, Krebber H, Kempf T, Hermes I, Ponstingl H (1995b) Human RanGTPase-activating protein RanGAPI is a homolog of yeast Rnalp involved in $\mathrm{mRNA}$ processing and transport. Proc Natl Acad Sci USA. 92:1749-1753

Boeke JD, LaCroute F, Fink GR (1984) A positive selection for mutants lacking ortidine- $5^{\prime}$-phosphate decarboxylase activity in yeast. Mol Gen Genet 197:345-346

Boguski M S, McCormick F (1993) Proteins regulating Ras and its relatives. Nature 366:643-653

Clark KL, Sprague GF Jr (1989) Yeast pheromone response pathway: characterization of a suppressor that restores mating to receptorless mutants. Mol Cell Biol 9:2682-2694

Dingwall CD, Kandels-Lewis S, Seraphin B (1995) A family of Ran binding proteins that includes nucleoporins. Proc Natl Acad Sci USA 92:7525-7529

Drivas GT, Shih A, Coutavas E, Rush MG, D'Eustachio P (1990) Characterization of four novel RAS-related genes expressed in a human teratocarcinoma cell line. Mol Cell Bio. 10:1793-1798

Hill J, Donald K, Griffiths DE (1991) DMSO-enhanced whole cell yeast transformation. Nucleic Acids Res 19:5791

Hill JE, Myers AM, Koerner TJ, Tzagoloff A (1986) Yeast/E. coli shuttle vectors with multiple unique restriction sites. Yeast $2: 163-167$

Hopper AK, Banks F, Evangelidis V (1978) A yeast mutant which accumulates precursor tRNAs. Cell 19:211-219

Izaurralde E, Mattaj IW (1995) RNA export. Cell 81:153-159

Kadowaki T, Goldfarb D, Spitz LM, Tartakoff AM, Ohno M (1993) Regulation of RNA processing and transport by a nuclear guanine nucleotide release protein and members of the Ras superfamily. EMBO J 12:2929-2937

Kai R, Ohtsubo M Sekiguchi M, Nishimoto $T$ (1986) Molecular cloning of a human gene that regulates chromosome condensation and is essential for cell proliferation. Mol Cell Biol $6: 2027-2032$

Kaiser C, Michaelis S, Mitchell A (1994) Methods in yeast genetics. Cold Spring Harbor Laboratory Press, Cold Spring Harbor New York

Leung DW, Chen E, Goeddel DV (1989) A method for random mutagenesis of a defined DNA segment using a modified polymerase chain reaction. Techniques $1: 11-15$

Loeb JD, Schlenstedt G, Pellman D, Kornitzer D, Silver PA, Fink GR (1995) The yeast nuclear import receptor is required for mitosis. Proc Natl Acad Sci USA 92:7647-7651

Matsumoto T, Beach D (1991) Premature initiation of mitosis in yeast lacking $\mathrm{RCCl}$ or an interacting GTPase. Cell 66:347-360

Melchior F, Paschal B, Evans J, Gerace L (1993) Inhibition of nuclear protein import by nonhydrolyzable analogs of GTP and identification of the small GTPase Ran/TC4 as an essential transport factor. J Cell Biol 123:1649-1659
Moore MS, Blobel G (1993) The GTP-binding protein Ran/TC4 is required for protein import into the nucleus. Nature 365:661663

Moreland RB, Langevin GL, Singer RH, Garcea RL, Hereford LM (1987) Amino acid sequences that determine the nuclear localization of yeast histone 2B. Mol Cell Biol 7:4048-4057

Muhlrad D, Hunter R, Parker R (1992) A rapid method for localized mutagenesis of yeast genes. Yeast 8:79-82

Nishiwaki K, Hayashi $\mathrm{N}$, Irie $\mathrm{S}$, Chung D-H, Harashima S, Oshima Y (1987) Structure of the yeast HIS5 gene responsive to general control of amino acid biosynthesis. Mol Gen Genet 208:159-167

Noguchi E, Hayashi N, Nakashima N, Nishimoto T (1997) Yrb2p, a Nup2p-related yeast protein has functional overlap with Rnalp, yeast RanGAP protein. Mol Cell Biol 17:2235 2246

Ohba T, Seki T, Azuma Y, Nishimoto T (1996) Premature chromatin condensation induced by loss of RCCl is inhibited by GTP- and GTP $\gamma$ S-Ran, but not GDP-Ran. J Biol Chem 271:14665-14667

Ohtsubo M, Kai R, Furuno N, Sekiguchi T, Sekiguchi M, Hayashida H, Kuma K, Miyata T, Fukushige S, Murotsu T, Matsubara K, Nishimoto T (1987) Isolation and characterization of the active cDNA of the human cell cycle gene(RCCl) involved in the regulation of onset of chromosome condensation. Genes Dev 1:585-593

Parent SA, Fenimore CM, Bostian KA (1985) Vector systems for the expression, analysis and cloning of DNA sequences in S. cerevisiae. Yeast 1:83-138

Richards SA. Carey KL, Macara IG (1997) Requirement of guanosine triphosphate-bound Ran for signal-mediated nuclear protein export. Science 276: 1842-1844

Sazer S (1996) The search for the primary function of the Ran GTPase continues. Trends Cell Biol 6:81-85

Sazer S, Nurse P (1994) A fission yeast RCCl-related protein is required for the mitosis to interphase transition. EMBO J 13:606-615

Seki T, Hayashi N, Nishimoto T (1996) RCCl in the Ran pathway. J Biochem 120:207-214

Schlenstedt G, Saavedra C, Loeb ID, Cole CN, Silver PA (1995a) The GTP-bound form of the yeast Ran/TC4 homologue blocks nuclear protein import and appearance of poly $(\mathrm{A})^{+}$RNA in the cytoplasm. Proc Natl Acad Sci USA 92:225-229

Schlenstedt G, Wong DH, Koepp DM, Silver PA (1995b) Mutants in a yeast Ran binding protein are defective in nuclear transport. EMBO J 14:5367-5378

Yokoyama N, Hayashi N Seki T, Pante N, Ohba T, Nishii K, Kuma K, Hayashida T, Miyata T, Aebi U, Fukui M, Nishimoto $\mathrm{T}$ (1995) A giant nucleopore protein that binds Ran/TC4. Nature 376:184-188

Wong DH, Corbett AH, Kent HM, Stewart M, Silver PA (1997) Interaction between the small GTPase Ran/Gsplp and $\mathrm{Ntf2} \mathrm{p}$ is required for nuclear transport. Mol Cell Biol $17: 3755-3767$

Wu J, M Matunis J, Kraemer D, Blobel G, Coutavas E (1995) Nup358, a cytoplasmically exposed nucleoporin with peptide repeats, Ran-GTP binding sites, zinc fingers, a cyclophilin $A$ homologous domain, and a leucine-rich region. J Biol Chem $270: 14209-14213$ 